\title{
Understanding Grief and Symbolism in Three Billboards Outside Ebbing, Missouri
}

\author{
$1^{\text {st }}$ Galih Bramantyo \\ English Studies Program, Faculty \\ of Humanities, \\ Universitas Indonesia \\ Depok, Indonesia \\ galih.bramantyo@ui.ac.id
}

\author{
$2^{\text {nd }}$ Marti Fauziah Ariastuti* \\ Linguistics Department, Faculty of \\ Humanities \\ Universitas Indonesia \\ Depok, Indonesia \\ marti.fauziah@ui.ac.id
}

\begin{abstract}
Grief is an intense feeling of loss. Studies on grief have often taken gender and psychological perspectives. This investigation adds to this extant body of literature, specifically scrutinizing the reactions of the characters in the movie Three Billboards Outside Ebbing, Missouri (2017) [1] to grief. It aims to analyze angerrelated tensions portrayed through symbolism and the violent outpouring of grief by the major characters of the movie. This study uses the qualitative research methodology to analyze data collected from particular scenes of the movie. This examination reveals that the male and female characters in the movie behave beyond the gender stereotypes that often describe males as more composed and restrained in their expressions of grief than women, who are said to be more openly articulate. Also, grief is symbolized in this film through the presence of specific elements such as the deer and the fire. Finally, this study also demonstrates two similarities that exist across gender constructs in the reactions to grief portrayed in the movie. Thus, the portrayal of grief in the movie is found to indicate that the American film industry no longer subscribes to clear-cut gender stereotypes in its depictions of bereavement.
\end{abstract}

Keywords-Three Billboards Outside Ebbing, indie movie, grief, gender, symbolism

\section{Introduction}

Grief may be defined in numerous ways. In general, however, the feeling of grief is exemplified by the response of individuals to the death of a loved one, or to the loss of a beloved object [2]. Grief is also described as the process of experiencing reactions to perceived loss [3]. More specifically, Gustafson [4] states that grief is associated with a psychological context such as the feelings of loss, pain, anger, fear, distress, and unhappiness. However, the intensity, duration, and experience of grief may vary greatly from person to person [5]. Thus, even though most negative and mournful emotions can be categorized as grief, the experience and duration of grief itself may vary according to individual psyches.

Previous studies on grief have mostly taken gender and psychological perspectives. For instance, Martin and Doka [6] have proposed a theory about grieving styles evinced by men and women. They distinguish grief into three categories: intuitive, instrumental, and blended. Intuitive grief is believed to be a more "feminine" way of grieving and involves the expression of felt emotion, and as a preference for feeling over thinking. Instrumental grief is thought to be a more "masculine" manner of grieving, involving physical expression, functional and active responses to grief, and a greater tendency to think rather than feel. It is, nonetheless, possible for people to evidence a mix of these two styles and to demonstrate a balance between feeling and thinking, displaying an emotional expression along with physical activities that may be categorized as functional. Such people may be said to show a blended grieving style.

Another study by Stinson, Lasker, Lohmann, and Toedter [7] also examined grief from a gender perspective, but in a more specific context, the loss of a child. These authors compared the coping mechanisms related to grief as evinced by men and women in cases of miscarriages or fetal death. They concluded that men may be inclined to deny their grief over the death of a child, in part because gender stereotypes call for men to be strong and unemotional. In so doing, men are prevented from coping adaptively with their loss. However, research conducted by Prigerson et al. [8] found no main effects that could be attributed to gender or time for any of the symptoms of complicated grief. The symptoms of grief can take the form of emotional shock, helplessness and avoidance (avoiding reminiscence of the deceased), anger, guilt, confusion, grief resolution behaviors, psychological strength-building, and coping. Melucci's study [9] also reported that people who have experienced loss may see themselves in someone who is still immersed in the grieving period. In other words, people can experience grief empathetically. Versalle and McDowell [10] discuss the differences between men and women in extending and receiving sympathy in times of grief. They claim that women tend to be more sympathetic than men toward others who are grief-stricken.

The study of symbolism in movies is an aspect of the discipline of semiotics, which attends to the social implications of signs. A sign is the basic unit of communication and can take the form of words, sounds, or objects [11]. Signs are divided into two constituent elements: the signifier and the signified. The signifier is the physical form of a sign such as a picture or a word. It conveys meaning and carries connotations [12]. Conversely, the signified is the object that is meant to be indicated by the signifier [13]. Thus, a signifier has no meaning without a signified, and that the signified meaning depends on 
the viewer and the context of the signifier. In other words, a movie combines discrete images to create a particular story, and every image contains the potential to convey several meanings. Building on Saussure's work on semiotics, Barthes [12] stated that a sign has both denotative (first-order) and connotative (secondorder) significations. Therefore, one signifier may transmit multiple and diverse connotative meanings according to a viewer's contextual understanding and interpretation.

The 2017 movie, Three Billboards Outside Ebbing, Missouri [1], was selected as the corpus of the present study. This film was directed by Martin McDonagh and was categorized as an indie movie. Despite being an independent movie, it won several prestigious awards for multiple categories at the Academy Awards, Golden Globes, and BAFTA. The genre of the film is crime drama; however, it incorporates very strong psychological elements. Most notably, it depicts grief very differently from other similar movies such as A Single Man (2009) or Manchester by the Sea (2016). It mixes overwhelming grief with dark humor, creating an unorthodox and engaging experience for viewers. The movie is focused on Mildred Hayes, a woman who seeks truth and justice for her teenage daughter's unsolved rape and murder, and demands justification of the police force's failure to capture the perpetrators of the crime. All the major characters of the film are male, except Mildred Hayes. Mildred uses three billboards as her preferred media for communication rather than the newspaper, radio, or television. Through the billboards, she satirizes the local police force, which has failed to conduct a due investigation to discover her daughter's murderer.

Different aspects of the movie have already been widely discussed by other scholars and film critics. For instance, Matthews [1] has examined the lead female character, Mildred, in the movie, attending to her harsh and courageous character and her traits such as stubbornness, ambition, vengefulness, selfish ideas, coarse manner of speaking, and acts of cruelty. Manzella's study [14] has underscored the moral import of the movie, arguing that people must undergo excessive trials and tribulations before they can achieve the state of mutual care and attention and realize that they need each other. Revenge is another aspect of the movie that has caught the attention of critics. In his article, Beck [15] has delved into the manner in which hatred becomes the major factor motivating some of the characters to execute extreme acts of revenge.

None of the numerous studies that have thus far been conducted on the movie [7], [8], [9], [10] have discussed gender-based grief and its symbolism. These two aspects are noteworthy in Three Billboards Outside Ebbing, Missouri [1]. This study, therefore, aims to fill this research gap through an exploration of how grief and its reactions, as conveyed through certain symbols, can exhibit variations as well as similarities across the genders. The investigation also explores the differences and similarities in the responses articulated by men and women in dealing with grief. To achieve this purpose, this paper contemplates the characterization, particular scenes, dialogs, and symbols such as the deer, the billboards, and fire. This article is arranged in three sections: first, it examines the gender opposition established between the main characters in the ways in which they cope with grief; second, the symbolism of fire and pain in the movie is discussed; third, some similarities that, in fact, exist in the way men and women mourn are elucidated. Further, the present study differentiates itself from the extant research on Three Billboards Outside Ebbing, Missouri (2017) through its focus on the use of symbols in certain scenes and the insights that they offer into the depiction of grief in the movie.

\section{Method}

This study utilizes the qualitative approach to explore the relationship between gender, symbolism, and expressions of grief in Three Billboards Outside Ebbing, Missouri (2017) [1]. The data for the investigation are gleaned from the film on the basis of several considerations such as the context of a scene and the hidden meanings of symbols in some frames. The data collection was conducted over several stages that included the selection of specific scenes that encompassed the showcasing of relevant aspects of grief felt by the major characters and the appearance of certain symbols in those scenes, such as the presence of an animal, certain behaviors demonstrated by the major characters, and several particular events that they are shown to experience. Finally, the collected data were analyzed through the perspective of the theoretical framework of semiotics. This last stage of the study included the application of the Martin and Doka's [6] theory of grieving styles and Barthes' [12] conceptions of the associations between connotation, culture, and meaning.

\section{Results and Discussion}

\section{A. Gender Differences in Grieving and the Symbols of Grief}

The two main characters of the movie, Mildred and her son Robbie, express their loss and anger in very different ways. Mildred openly articulates her grief. For instance, she wants everyone to know that she is still grieving the loss of her daughter and is unwilling to cope with her loss. Mildred even takes extreme action by renting three billboards to satirize the local police and their failure to advance in their investigations into her daughter's rape and murder. The first billboard says, "How come, Chief Willoughby?" The second one is, "And still no arrests?" and the third one is, "Raped while dying." By renting and displaying the billboards, Mildred hopes to provoke the local police and to pressurize them to find the man who raped and killed her daughter. In contrast, Robbie's very different response can be noted in the scene in which he informs his mother about his feelings about the billboards:

Great! Rape while dying route home. Because two seconds I was not thinking about her and 
thinking about how she died. There you go, think about her some more. Good, too, cause as much when I try to avoid the detail of what happened because I did not do anything, I could not bear it. It is also good to be informed in 20-foot-high far with real nice lettering in precise detail of her last moment, that she was not enough to be raped, and was not enough that she died. No! Raped while dying! Thank you, mom" (00:32:30).

Robbie expresses his true feelings about his sister's death and conveys his discomfort at the intimidating messages displayed on the billboards. However, he only dares to express his anger to his mother when talking to her face-to-face. He does not have the courage to articulate it in front of other people and prefers to keep his anger to himself.

The presence of the deer in the movie is not without deeper significance. Applying Barthes' [12] theory, the deer denotes the meaning of an animal with four legs that eats grass for sustenance. However, its connotative meaning becomes apparent when a Native American myth is taken into account. A deer symbolizes persistence in Native American mythology. It also serves as a reminder to people to live their lives with grace [16]. This symbolization is directed at Mildred to urge her to continue her quest for justice for her daughter's rape and murder. After an encounter with the deer, Mildred always finds ways to overcome every obstacle that comes in the way of her renting the billboards. In addition, for people who have lost a family member or someone they love, the presence of a deer signifies that the departed is in a better place in the afterlife and that they are not alone [17]. This solace motivates Mildred to stop grieving over the death of her daughter and to focus on hunting down the perpetrator of the heinous crime.

Silence can also symbolize grief, although it can be ambiguous and is not limited to any particular interpretation [18]. Mildred enters her daughter's room in one scene. As she sits on her daughter's bed, she has a sudden flashback of her last conversation with her daughter (00:34:00). Her daughter, was upset with her because Mildred had refused to let Angela, her daughter, borrow her car on the day she was raped and killed. Mildred carries the guilt of not letting Angela use the car: if she had, her gruesome death may have been prevented. Then Mildred stands and walks quietly to the bedroom's door. She turns around and stares into the room. There is no dialog, only the flashback conversation. She stands there, in silence, with a flat expression. Applying Barthes' [12] theory, Mildred's numbness conveys two levels of signification. In denotative terms, her numbness is represented by the pale-faced woman who stands still without uttering a word. The connotative meaning of the silent scene conveys her guilt, self-blame, failure, and loss so extreme that no words can express them.

In opposition, Robbie's silence signifies a different emotion from Mildred's as shown in the scene where Robbie slams his bedroom door $(00: 33: 24)$. The incident is triggered by the high-tension conversation about the billboards between Robbie and his mother in the car (00:32:30). The silence after he slams the door represents the culmination of his anger, which is contrasted with the remorseful undertones of Mildred's silence. In this scene, Robbie is portrayed as undergoing an uncontrolled outburst of emotions. Using Barthes' [12] theory, this moment of silence conveys two levels of signification: denotatively, a man violently shuts a door; connotatively the slamming of the door manifests the strength of Robbie's anger and frustration. It is clear that Robbie is upset about his earlier conversation with his mother and is extremely disturbed by the whole idea of the billboards, which serve to him as a reminder of his sister's tragic death every time he passes them on his way home.

Mildred reacts more calmly to the death of her daughter. Her behavior shows that she has can wield a lot of control over herself. Her composure supports the theory of intuitive grief, which is expressed through calmness and controlled expression of emotions rather than through uncontrolled or physical articulation [6]. However, Mildred's behavior changes gradually and takes on a more aggressive character as time passes and the police cannot find the rapist-murderer of her daughter. Her aggression takes the form of the billboards that publicly mock the law and order authorities of the town. Thus, Mildred's coping behavior is marked by a blend of calmness and aggression. In contrast, Robbie is very emotional at the beginning of the movie. His grief is expressed through the harsh words he utters and his action of slamming his bedroom door. Robbie's behavior, therefore, is congruent with Martin and Doka's [6] definition of instrumental grief. Meanwhile, Baddeley and Singer's theory [18] is relevant to the discrete interpretations of the moments of silence in the movie: Mildred's silence symbolizes her guilt and her sense of failure for not being able to resolve her daughter's death; Robbie's silence represents his anger and frustration.

\section{B. Fire and Pain as Dual Symbols}

Fire is normally associated with anger. People perceive of fire as something dangerous, harmful, and vindictive. In this movie, the element of fire symbolizes vengeance for Mildred and punishment for Dixon, the police officer who handles Angela's case. Mildred witnesses her billboards being burned down by an unknown perpetrator (01:11:18). Despite her efforts, she fails to extinguish the fire and the billboards are charred to ashes. She falls down on her knees and watches the as fire burns her billboards. In this scene, the fire hurts Mildred implicitly. The billboards, as her last hope for justice and her primary means of expressing her grief to the world, are gone. At the same time, the fire that she sees on the billboards spurs her to take revenge and act more violently. She suspects that the fire has been deliberately set by some police officers who could not take the criticism. Thus, she takes her revenge by burning down the police station with her handmade Molotov cocktail. 
In contrast, fire has a different meaning for Dixon. When he realizes that his office is on fire, he immediately grabs Angela's case files and jumps out of his office (01:20:50). Despite burning down the billboards and injuring the man from the advertising agency, Dixon learns that he has made a big mistake after reading a letter sent to him by his superior, Chief Willoughby, who is terminally ill and is no longer able to work on Angela's rape and murder case. The letter, which contains Willoughby's last words, encourages Dixon to complete the investigation. The fire that breaks out in his office may be perceived as punishment for Dixon's past deeds. At the same time, this fire also purifies him as he consequently exhibits a strong resolve and willingness to compensate for his wrongdoings by saving Angela's case files from the fire. Thus, fire may be perceived as a form of punishment, but it may also be viewed as a purifier that destroys past sins. Dixon's experience with fire bears similarities to the Bible's statement about humans' faith and deeds in connection to the element of fire, specifically in Corinthians 3: 10-15 10. One study has interpreted this verse to signify that people who build a foundation (faith) in malicious ways will be punished in hell [19]. On the other hand, people who build their faith in a benevolent way will be saved by the fire [19]. In other words, fire is given a unique and important role in this verse: it serves as both punishment and reward depending on the nature of the foundation that people have built during their lives.

Pain may represent a deeper meaning for Dixon, but it also carries a literal meaning. On one hand, Dixon endures physical pain as he escapes from the incinerated police office: he is burned as he attempts (and manages) to save Angela's case files from the fire. Dixon is also physically injured by a person he suspects is Angela's murderer (01:32:09). Despite the pain that results from the assault, Dixon succeeds in obtaining the suspect's DNA, which he then uses to prove that the man is the actual murderer. Barthes' [12] theory can again be applied to Dixon's pain, which conveys both denotative and connotative meanings: denotatively, it refers to the physical or mental feeling of suffering caused by an injury or loss; connotatively, it serves as punishment for someone who has done bad things before [20] but can also refer to the painful purifying process one must undergo to become a better person in the future [20]. To experience purification, a person must deal with and experience some painful moments in life. Dixon succeeds in purifying himself of his past wrongdoings by enduring the pain and suffering of being burned and being beaten to benefit others.

\section{Reactions During the Grieving Period: Similarities Across the Genders}

The major characters of this film demonstrate similar reactions during their grieving period regardless of gender differences. The first and most spontaneous reaction is crying. Mildred sheds copious tears when she sees the deer that leaves her alone under the billboards (00:46:31). Similarly, Chief Willoughby's wife, Anne, also cries in two scenes: first, when she becomes aware that her husband has killed himself (00:53:06), and second when she hands her husband's letter to Mildred at the souvenir store (01:06:34). Similarly, Dixon also cries twice in the movie: first, when he hears the news of the death of his boss (00:55:36), and second when he finds out that he occupies the same room as Welby in the hospital (01:23:52). Likewise, Dixon's mother, Momma Dixon, also sobs when she is prevented from helping her son, who is suffering in the bathroom because of his earlier fight with a man at the bar (01:37:17). Essentially, people are often shown to cry because of the helplessness they feel. The diverse situations of crying [21] are mostly related to feelings that can be categorized as physical pain, separation and loss, failure, anger, and guilt [21] which cause people to cry.

Miceli and Castelfranchi [21]'s concepts elucidate that the underlying reason for Mildred's crying situation can be determined to be her sense of loss, separation, and failure. The feeling of loss and separation stems from her realization that Angela is dead; her sense of failure emanates from her inability to protect Angela from being raped and murdered. Likewise, Dixon's crying situation when he hears the news about his dead boss, and Anne's crying situations can also be labeled as being caused by feelings of separation and loss. The sense of loss arises from reminders that people close to them are gone and that they will never see them again. Just like Mildred, Momma Dixon's crying situation is also caused by her sense of separation and failure. Her separation results from the fact that her desire to help Dixon is snubbed and he isolates himself from her by locking the bathroom door. She cannot help her son inside the bathroom and she whimpers as she begs him to open the door. Meanwhile, her failure derives from her unsuccessful attempt to assist Dixon because he denies her the opportunity to help by locking the bathroom door.

Dixon's second crying situation regarding Welby, the man he assaulted, also results from reasons similar to Mildred's because he feels guilty about causing harm to others. Dixon begins to cry when he sees Welby in the same hospital room he occupies. Guilt sweeps over him as he realizes that he has brought this suffering upon Welby. Likewise, the deer reminds Mildred of her deceased daughter and she remembers her refusal to lend her daughter the car which might have prevented her murder, and is swept by feelings of guilt. In addition, Dixon's crying situation is supported by Ross and Mirowsky's study [22], which shows that inexpressiveness is not static in men; some men are more likely to cry than others. It also contradicts the societal expectation that men should not express emotions of sadness through crying [22]. Both male and female characters in the movie convey their emotions through their tears, albeit in different situations and occasions. There also exist similarities between male and female characters with regard to Miceli and Castelfranchi's [21] theory about the causes of crying situations. Both genders in the movie share two similar reasons for their crying situations: 
loss and failure. Thus, the stereotype that "boys don't cry" is not applicable to this movie, which encourages the idea that men can also cry when they experience feelings of separation and loss. The fact that a stereotypically masculine character such as Dixon is seen weeping and reveals his sensitive aspect proves that this movie validates emotional expression by its male characters.

The second reaction to grief portrayed in the movie is aggressive behavior. Two characters, Mildred and Dixon, engage in violent acts because they are angry about events that occur as they are grieving. Bonanno and Kaltman [23] claim that anger is a common component of bereavement, which also elicits affects such as numbness, despair, fear, and guilt. In other words, people who are grieving are often angry, but the intensity of the emotion may vary from one individual to another. Mildred's anger is directed at the policemen who, she suspects, have burned her billboards. The billboards are her way of expressing her bereavement. The billboard burning incident triggers her act of revenge. She sets the police station on fire (01:19:27). Her desire for revenge prevents her from realizing that she is committing an act of vandalism. In a similar vein, Dixon's anger at the news of his boss's death finds expression in his assault of Welby. He punches, kicks, and throws Welby out of the window of the second floor of the Ebbing Advertisement Office (00:58:03). Further, Mildred's act of violence contradicts the cultural assumption of gender as outlined in Hume's study [24], which posits that men feel they have more "right" to use violence than women since physical force is socially established as an aspect of masculinity. In addition, the word "right" justifies violence by men, while women are considered unfeminine if they resort to physical aggression. Mildred's act of violence may prove that the right to use physical force is, in fact, not limited to any particular gender. Women can also resort to violence, especially as a response to grief.

\section{Conclusions}

To summarize, the above discussions indicate two major findings. First, gender differences do exist in the handling of grief as displayed by the film's characters. Seen from the lens of Martin and Doka's [6] theory, Mildred undergoes a gradual change in her grieving style as she shifts from the intuitive style of grieving when she acts calmly toward the deer, to the blended style when she rents the billboards and burns down the police station with a Molotov cocktail. Meanwhile, Robbie and Dixon show a static manner of grieving in the instrumental style. Both the male characters express grief in a more physical manner from the beginning of the movie as is evidenced in certain scenes such as Robbie's high volume while speaking, the slamming of the door, and Dixon's assault on Welby. However, the above analysis also reveals similar reactions expressed across the genders during the grieving period. Crying and violent actions are the two similarities observed across the genders in reactions to grief. Mildred, Dixon, and Anne evince similar reactions to their grief by crying. In terms of
Miceli and Castelfranchi's [21] theory, Mildred's crying situation can be attributed to her sense of loss and her separation from her daughter, while Dixon's crying situation can be attributed to his guilt from assaulting Welby. Further, Mildred and Dixon's acts of violence are driven by anger that increases in intensity as they cope with their grief.

Further studies on the topic could discuss grief from other perspectives such as social hierarchy, familial relationships, occupation, ethnicity, or religion. For example, one's social background may affect the way one grieves. This study acknowledges certain limitations with regard to particular topics, such as the objects of symbolism, gender, responses to grief, and symbolism. Because of its limited scope, other important topics related to grief, gender, and symbolism can be explored further to attain more comprehensive insights. Such themes for future studies could include gender differences with regard to particular psychological factors and their effects on those who are grieving, gender stereotypes regarding grief, and the different forms of grief and coping systems exhibited by specific groups of people. Since this research project is only based on one movie, it would be interesting to probe whether the genderbased depictions of grief in other films also challenge existing stereotypes or conform to prevailing social norms vis-à-vis gender.

\section{References}

[1] Matthews, J. (2017, December 29). Three Billboards Outside Ebbing, Missouri (Movie Review). Retrieved from https://digitalcollections.dordt.edu/cgi/viewcontent.cgi?article $=1853 \&$ context $=$ faculty_work

[2] Cowles, K. V. (1996). Cultural Perspectives of Grief: An Expanded Concept Analysis. Journal of Advanced Nursing, 23(2), 287-294.

[3] Rando, T. A. (1993). Treatment of Complicated Mouming. Champaign, Illinois: Research Press

[4] Gustafson, D. (1989). Grief. Nô̂s, 23(4), 457-479.

[5] Zisook, S., \& Shear, K. (2009). Grief and Bereavement: What Psychiatrists Need to Know. World Psychiatry, 8(2), 67-74.

[6] Martin, T. L., \& Doka, K. J. (2000). Men Don't Cry... Women Do: Transcending GenderStereotypes of Grief. Philadelphia, PA: Brunner/Mazel.

[7] Stinson, K. M., Lasker, J. N., Lohmann, J., \& Toedter, L. J. (1992). Parents' Grief Following Pregnancy Loss: A Comparison of Mothers and Fathers. Family Relations, 41(2), 218.

[8] Prigerson, H. G., Maciejewski, P. K., Reynolds, C. F., Bierhals, A. J., Newsom, J. T., Fasiczka, A., Frank, E., Doman, J., \& Miller, M. (1995). Inventory of Complicated Grief: A Scale to Measure Maladaptive Symptoms of Loss. Psychiatry Research, 59(1-2), 65-79.

[9] Melucci, A. (1989). Nomads of the Present: Social Movements and Individual Needs in Contemporary Society. Philadelphia, PA: Temple University Press.

[10] Versalle, A., \& McDowell, E. E. (2005). The Attitudes of Men and Women Concerning Gender Differences in Grief. Omega, 50(1), 53-67.

[11] Turner, G. (2006). Film as Social Practice: Fourth Edition. London: Routledge.

[12] Barthes, R. (1964). Elements of Semiology. New York: HILL and WANG.

[13] Saussure, F. D. (1974). Course in General Lingustics. London: Sage Publications. 
[14] Manzella, A. G. H. (2018). Violence and Care in Three Billboards Outside Ebbing, Missouri. Retrieved from https://quod.lib.umich.edu/f/fc/13761232.0042.302/--

violence-and-care-in-three-billboards-outsideebbing?rgn=main; view=fulltext

[15] Beck, B. (2018). Heartland: Forgiveness in Columbus, Three Billboards Outside Ebbing, Missouri, and Lady Bird. Multicultural Perspectives, 20(2), 92-95.

[16] Lake-Thom, B. (1997). Spirits of the Earth: A Guide to Native American Nature Symbols, Stories, and Ceremonies. London: Penguin.

[17] Beidler, P. G. (1979). Animals and Theme in "Ceremony." American Indian Quarterly, 5(1), 13-18.

[18] Baddeley, J., \& Singer, J. A. (2010). A Loss in the Family: Silence, Memory, and Narrative Identity after Bereavement. Memory, 18(2), 198-207.
[19] Townsend, J. T. (1968). 1 Corinthians 3:15 and the School of Shammai. Harvard Theological Review, 4(3), 500-504.

[20] Conwill, W. L. (1986). Chronic Pain Conceptualization and Religious Interpretation. Journal of Religion and Health, 25(1), 46-50.

[21] Miceli, M., \& Castelfranchi, C. (2003). Crying: Discussing Its Basic Reasons and Uses. New Ideas in Psychology, 21(3), 247-273.

[22] Ross, C. E., \& Mirowsky, J. (1984). Men Who Cry. Social Psychology Quarterly, 47(2), 138-146.

[23] Bonanno, G. A., \& Kaltman, S. (2001). The Varieties of Grief Experience. Clinical Psychology Review, 21(5), 705-734.

[24] Hume, M. (2008). The Myths of Violence. Latin American Perspectives, 35(5), 59-76. 